\title{
EVALUATION OF ANTI-INFLAMMATORY AND ANALGESIC ACTIVITY OF THE AQUEOUS METHANOLIC EXTRACT OF ASPRARAGUS RACEMOSUS IN EXPERIMENTAL MODELS
}

\author{
HASEEB AHSAN $^{1 *}$, IHTISHAM HAIDER ${ }^{2}$, MUHAMMAD NAVEED MUSHTAQ ${ }^{3}$, IRFAN \\ ANJUM $^{3}$ \\ ${ }^{I}$ College of pharmacy, University of Sargodha, Sargodha, Pakistan \\ ${ }^{2}$ Nawaz Sharif medical college, University of Gujrat, Pakistan \\ ${ }^{3}$ Faculty of Pharmacy, Department of Pharmacology, The University of Lahore, Lahore, Pakistan
}

*corresponding author: haseeb.ahsan@uos.edu.pk

Manuscript received: March 2018

\begin{abstract}
The aim of the present study was to evaluate the anti-inflammatory and analgesic activity of the aqueous methanolic extract of the root of Asparagus racemosus in Albino mice model. Oedema models were induced by injection of carrageenan and fresh egg albumin into right hind paw. Acetic acid and formalin were used to induce pain models. The aqueous methanolic extract showed significant reduction in both paw oedema models. In pain models, the extract also significantly inhibited the acetic acid-induced writhing and formalin-induced paw lickings. Our findings showed that aqueous methanolic extract of Asparagus racemosus's root reduced inflammation and pain in experimental models. The results proposed a potential use of Asparagus racemosus's roots in treating conditions associated with inflammation and pain.
\end{abstract}

\section{Rezumat}

Scopul studiului a fost de a evalua activitatea antiinflamatorie și analgezică a extractului hidroalcoolic din rădăcina de Aspraragus racemosus într-un model experimental murin. Edemul a fost indus prin injectarea de carragenan și albumină proaspătă din ou în laba dreaptă din spate. S-au folosit acid acetic şi formalină pentru a induce modele de durere. Extractul hidroalcoolic a demonstrat o reducere semnificativă a ambelor modele de edem de labă. În modelele de durere, extractul inhibă, de asemenea, în mod semnificativ simptomatologia specifică fiecărui test. Constatările noastre au arătat că extractul hidroalcoolic din rădăcina de Aspraragus racemosus a redus inflamația și durerea în modelele experimentale testate. Rezultatele au sugerat o posibilă utilizare a rădăcinilor Aspraragus racemosus în tratarea afecțiunilor asociate cu inflamația și durerea.

Keywords: Asparagus racemosus, anti-inflammatory, carrageenan, pain, formalin

\section{Introduction}

Inflammation is a primary defence mechanism and protects body against toxic substances, allergens, infections and a number of harmful agents. Under various pathophysiological conditions, the inflammation process becomes uncontrolled and leads to chronic diseases [1]. Generally, inflammation is regarded as a protective response intended to eliminate causes of injury such as noxious chemicals or microbial agents [2]. It is a complicated process that is mediated by variety of signals produced by leukocytes, macrophages and mast cells. Cyclooxygenases (COX) play a key role in the production of potent pro-inflammatory prostaglandins (PGs) [3]. Different synthetic drugs are used as anti-inflammatory agents. These include narcotics e.g., opioids or non-narcotics e.g., salicylates and corticosteroids e.g., hydrocortisone [4]. But the side effects of the currently available anti-inflammatory drugs present a major problem. Hence there is need to develop safe drugs. Asian have written evidence for the use of natural products for various disease [5]. Traditionally, natural products are approved as safe drugs in most of the societies as compare to allopathic medicines [6].A large number of phytochemicals isolated from natural sources have been used to treat inflammation and other pain-associated conditions. These phytochemicals showed low toxicity and higher therapeutic effect [7].

Asparagus racemosus is a commonly occurring plant in Punjab, Pakistan from Liliaceae family. The common name of this plant is satmuli and the part used as therapeutic agent is the root. It normally grows at the height of 1 - $2 \mathrm{~m}$, presenting needles like leaves and white flowers [8].

Asparagus racemosus is used traditionally as carminative, antispasmodic, antidiarrheal and in dyspepsia and rheumatism [9]. There is a need to prove its biological activities pharmacologically. The aim of the present study was to evaluate the anti-inflammatory and analgesic activity of the aqueous methanolic extract of the root 
of Asparagus racemosus (AMEAC) in carrageenan and albumin- induced paw oedema and formalininduced paw licking and acetic acid-induced abdominal writhing in albino mice respectively.

\section{Materials and Methods}

\section{Plant Material}

The plant Asparagus racemosus was collected from Gujrat, Pakistan. The plant was identified by Dr. Amin Ullah Shah, Department of Botany, University of Sargodha, Pakistan. The extraction of the root of Asparagus racemosus (4 kg) was performed by cold maceration method by adding $9 \mathrm{~L}$ (70:30 ratio of methanol to distilled water) solvent. The powder was soaked for 72 hours at room temperature with infrequent shaking and filtered through muslin cloth and Whatman qualitative Grade 1 filter paper. The final filtrate was evaporated with the help of rotary evaporator and then lyophilized to give a yield of $4.8 \%$ of extract. The extract was dissolved in distilled water for administration $[10,11]$.

Animals

Adult healthy Swiss albino mice of both sexes weighing 20 - $30 \mathrm{~g}$ were used for this study. The polypropylene cages were used for housing and animals were allowed free access to water and were given palatable clean food. Humidity and temperature of the animal house were maintained constant. Dark and light cycle of 12/12 hours was preserved. The National Institute of Health (NIH) guidelines were followed for the treatment of these animals. The followed experimental protocol was according to internationally approved guidelines (Guide for the care and use of laboratory animals, NIH, United States) for animal use and care. The animals were acclimatized for a period of 7 days. The study protocols were approved by the local ethical committee of the University of Sargodha, Pakistan.

\section{Drug administration}

The extracts were administered to the animals by the following routes.

\section{Oral administration}

Oral gavage was used for administration of plant extract and standard drug. The needle of the $1 \mathrm{cc}$ BD syringe was removed and Ryle tube \#4 attached to needle no. 17 was used.

\section{Anti-inflammatory activity}

Carrageenan-induced paw oedema in mice

Anti-inflammatory activity of aqueous methanolic extract in 250 and $500 \mathrm{mg} / \mathrm{Kg}$ bw doses was performed by using carrageenan-induced paw oedema model in mice [12]. Twenty animals were divided into four groups having five animals each. Group I received distilled water ( $2 \mathrm{~mL} / \mathrm{kg}$ bw p.o.) and served as control group. Group II and III received aqueous methanolic extract of Asparagus racemosus in 250 and $500 \mathrm{mg} / \mathrm{kg}$ bw p.o. doses respectively through oral route. Group IV received the drug ibuprofen in $40 \mathrm{mg} / \mathrm{kg}$ bw dose p.o. and was considered as standard group. One-hour post treatment, oedema was developed by injection of carrageenan $(0.1 \mathrm{~mL}, 1 \%$, w/v in saline) into the sub plantar tissue of the right hind paw. The linear paw circumference was then measured at 0 , $30,60,90$ and $120 \mathrm{~min}$. of the administration of phlogistic agent, using the vernier calliper. The \% inhibition was calculated by using the following formula:

$$
\text { Inhibition }(\%)=[(\mathrm{Vc}-\mathrm{Vt}) / \mathrm{Vc}] \times 100,
$$

where, Vc and Vt represent the average paw volume of the control and the treated animals respectively $[13,14]$.

Egg albumin-induced paw oedema in mice

The anti-inflammatory activity of the extract was also evaluated on egg albumin-induced inflammation model in mice by following the method described in literature with some modification [12]. Briefly, mice weighing $20-30 \mathrm{~g}$ were grouped into four groups consisting of five mice each. The animals were kept fasting for 12 hours before the beginning of the experiment. Group I (control) was treated with distilled water $2 \mathrm{~mL} / \mathrm{kg}$ bw orally. Animals of Groups II and III, were given aqueous methanolic extract of Asparagus racemosus in 250 and $500 \mathrm{mg} / \mathrm{Kg}$ bw doses orally, whereas Group IV (standard group) received ibuprofen as a standard drug ( $40 \mathrm{mg} / \mathrm{kg}$ bw p.o.). $0.1 \mathrm{~mL}$ of fresh egg albumin was injected into the paw to induce inflammation, after one hour of treatment. The linear diameter of paw was measured at $0,1,2$, and 3 hours after the administration of inflammatory agent using a vernier calliper. The above-mentioned formula was used to calculate \% inhibition [15].

Analgesic activity

The analgesic activity of the extract was assessed by using two models i.e., acetic acid-induced writhing model and formalin-induced paw licking model in mice.

\section{Acetic acid-induced writhing in mice}

The aqueous methanolic extract of Asparagus racemosus was evaluated for its analgesic activity using acetic acid induced writhing method in mice. The different groups of the animals were given the extract (250 and $500 \mathrm{mg} / \mathrm{kg} \mathrm{bw})$, ibuprofen $(40 \mathrm{mg} / \mathrm{kg} \mathrm{bw})$ and distilled water orally. After 30 minutes post treatment, acetic acid $(0.6 \%, \mathrm{v} / \mathrm{v}$ in saline, $10 \mathrm{~mL} / \mathrm{kg}$, i.p.) was injected to every mouse in order to induce pain. The number of writhings developed in each mouse after administration of acetic acid (characterized by contraction of the abdominal musculature and extension of the hind limbs) were observed after $5 \mathrm{~min}$ and continued for $10 \mathrm{~min}$.

$\%$ inhibition $=\{[$ No. of writhings $($ Control $)-$ No. of writhings (Treated)]/No. of writhings (Control) $\} \times 100$ 
FARMACIA, 2019, Vol. 67, 2

Formalin-induced paw licking in mice

Each dose of the aqueous methanolic extract, normal saline and standard drug (ibuprofen) were administered to 12 hour fasting mice divided into 4 groups of five mice each. Group I serving as control was treated with $2 \mathrm{~mL} / \mathrm{kg}$ bw saline, orally. Groups III and IV were treated with 250 and $500 \mathrm{mg} / \mathrm{kg}$ bw doses of the extract respectively, while Group IV was treated with $40 \mathrm{mg} / \mathrm{kg}$ bw p.o. of ibuprofen. Pain was induced by injection of $0.05 \mathrm{~mL}$ of $2.5 \%$ formalin into subplanter of right hind paw. The time that the mice spent licking the injected paw, was recorded and considered as indicative of pain. This response was calculated for 30 minutes. The percentage inhibition was calculated by the below given formula:

$\%$ Inhibition $=\{[$ Reaction Time $($ Control $)-$ Reaction

Time (Treated)]/Reaction Time (Control) $\} \times 100$
Statistical analysis

Data were analysed as mean \pm SEM. One-way ANOVA analysis followed by Dunnett's test was used to compare data with control group by using Graph pad prism 5 . Student $t$ test was applied in the case of paw licking and writhing data.

\section{Results and Discussion}

In the carrageenan-induced paw oedema model, the aqueous methanolic extract of Asparagus racemosus caused significant reduction of the swallowing induced in the paw. The plant extract in 250 and $500 \mathrm{mg} / \mathrm{kg}$ bw doses showed negligible reduction at 0 time. After 30 minutes of induction of oedema, both doses of extract caused significant anti-inflammatory effect comparable to control group at the respective time. As time proceeded, the extract produced a maximum inhibitory effect. Ibuprofen, used as a standard drug also produced a significant reduction of paw oedema compared to control group as shown in Table I.

Table I

Effect of aqueous methanolic extract of Asparagus racemosus at 250 and $500 \mathrm{mg} / \mathrm{kg}$ bw doses on carrageenan induced paw oedema in mice

\begin{tabular}{|c|c|c|c|c|c|}
\hline Treatment (Dose, $\mathrm{mg} / \mathrm{kg} \mathrm{bw}$ ) & $\begin{array}{l}0 \text { min }(\mathbf{m m}) \\
(\% \text { inhibition })\end{array}$ & $\begin{array}{l}30 \min (\mathrm{mm}) \\
(\% \text { inhibition) }\end{array}$ & $\begin{array}{l}60 \min (\mathrm{mm}) \\
(\% \text { inhibition) }\end{array}$ & $\begin{array}{c}90 \min (\mathrm{mm}) \\
(\% \text { inhibition }) \\
\end{array}$ & $\begin{array}{l}120 \min (\mathrm{mm}) \\
(\% \text { inhibition) } \\
\end{array}$ \\
\hline$(2 \mathrm{~mL} / \mathrm{kg} \mathrm{bw})$ & $3.11 \pm 0.049$ & $3.36 \pm 0.056$ & $3.58 \pm 0.071$ & $3.80 \pm 0.051$ & $4.0 \pm 0.045$ \\
\hline $\begin{array}{c}\text { Aqueous methanolic extract } \\
(250 \mathrm{mg} / \mathrm{kg} \mathrm{bw})\end{array}$ & $\begin{array}{c}3.06 \pm 0.084^{\text {n.s }} \\
(1.61 \%)\end{array}$ & $\begin{array}{c}2.94 \pm 0.07^{* * *} \\
(12.5 \%)\end{array}$ & $\begin{array}{c}2.80 \pm 0.17^{* * *} \\
(21.78 \%)\end{array}$ & $\begin{array}{c}2.72 \pm 0.13^{* * *} \\
(28.42 \%)\end{array}$ & $\begin{array}{c}2.76 \pm 0.11^{* * *} \\
(31 \%)\end{array}$ \\
\hline $\begin{array}{c}\text { Aqueous methanolic extract } \\
(500 \mathrm{mg} / \mathrm{kg} \mathrm{bw})\end{array}$ & $\begin{array}{l}3.01 \pm 0.12^{\text {n.s }} \\
\quad(3.21 \%)\end{array}$ & $\begin{array}{c}2.74 \pm 0.04^{* * *} \\
(18.45 \%)\end{array}$ & $\begin{array}{c}2.58 \pm 0.02^{* * *} \\
(27.93 \%)\end{array}$ & $\begin{array}{c}2.42 \pm 0.05^{* * *} \\
(36.31 \%)\end{array}$ & $\begin{array}{c}2.3 \pm 0.05^{* * *} \\
(42.5 \%)\end{array}$ \\
\hline Ibuprofen $(40 \mathrm{mg} / \mathrm{kg} \mathrm{bw})$ & $\begin{array}{l}3.08 \pm 0.05 \%{ }^{\text {n.s }} \\
(0.96 \%)\end{array}$ & $\begin{array}{c}2.7 \pm 0.32^{* * *} \\
(19.64 \%)\end{array}$ & $\begin{array}{c}2.59 \pm 0.12^{* * *} \\
(27.65 \%)\end{array}$ & $\begin{array}{c}2.44 \pm 0.21^{* * *} \\
(35.18 \%)\end{array}$ & $\begin{array}{c}2.34 \pm 0.14^{* * *} \\
(41.5 \%)\end{array}$ \\
\hline
\end{tabular}

Results are expressed as means \pm SEM $(\mathrm{n}=5)$ Key: where, $* * *=(\mathrm{p}<0.001)$ and $\mathrm{n} . \mathrm{s}=$ non-significant when compared to control.

The aqueous methanolic extract of Asparagus racemosus at both doses (250 and $500 \mathrm{mg} / \mathrm{kg}$ bw) showed significant reduction in the swollen paw induced by albumin from $30 \mathrm{~min}$ post phlogistic administration to $120 \mathrm{~min}$. But this extract caused a maximum inhibition

of the swollen paw after 2 hours of induction of oedema. Ibuprofen at a dose of $40 \mathrm{mg} / \mathrm{kg}$ bw also significantly reduced oedema, but this effect is time dependent. These results were comparable with control group as shown in Table II.

Table II

Effect of aqueous methanolic extract of Asparagus racemosus at 250 and $500 \mathrm{mg} / \mathrm{kg}$ bw on egg albumin-induced paw oedema in mice

\begin{tabular}{|c|c|c|c|c|c|}
\hline Treatment (Dose, mg/kg bw) & $\begin{array}{c}0 \min (\mathrm{mm}) \\
(\% \text { inhibition })\end{array}$ & $\begin{array}{c}30 \min (\mathrm{mm}) \\
(\% \text { inhibition) }\end{array}$ & $\begin{array}{r}60 \min (\mathrm{mm}) \\
(\% \text { inhibition) }\end{array}$ & $\begin{array}{c}90 \min (\mathrm{mm}) \\
(\% \text { inhibition) }\end{array}$ & $\begin{array}{l}120 \min (\mathrm{mm}) \\
(\% \text { inhibition) }\end{array}$ \\
\hline Control (2 mL/kg bw) & $3.28 \pm 0.15$ & $3.7 \pm 0.071^{* * * *}$ & $4.02 \pm 0.06^{* * *}$ & $4.4 \pm 0.1^{* * *}$ & $4.53 \pm 0.09^{* * *}$ \\
\hline $\begin{array}{c}\text { Aqueous methanolic extract } \\
(250 \mathrm{mg} / \mathrm{kg} \text { bw })\end{array}$ & $\begin{array}{l}3.16 \pm 0.15^{\text {n.s }} \\
(3.6 \%)\end{array}$ & $\begin{array}{l}3.14 \pm 0.14^{\mathrm{n} . \mathrm{s}} \\
(15.1 \%)\end{array}$ & $\begin{array}{c}3.05 \pm 0.08^{* *} \\
(24.1 \%)\end{array}$ & $\begin{array}{l}2.95 \pm 0.06^{*} \\
(32.9 \%)\end{array}$ & $\begin{array}{l}2.74 \pm 0.08^{*} \\
(39.5 \%)\end{array}$ \\
\hline $\begin{array}{c}\text { Aqueous methanolic extract } \\
(500 \mathrm{mg} / \mathrm{kg} \text { bw })\end{array}$ & $\begin{array}{c}3.24 \pm 0.09^{\text {n.s }} \\
(1.2 \%)\end{array}$ & $\begin{array}{c}3.04 \pm 0.08^{* *} \\
(17.8 \%)\end{array}$ & $\begin{array}{c}2.64 \pm 0.1^{* * *} \\
(34.3 \%)\end{array}$ & $\begin{array}{c}2.34 \pm 0.051^{*} \\
(46.8 \%)\end{array}$ & $\begin{array}{c}2.22 \pm 0.08^{* *} \\
(50.9 \%)\end{array}$ \\
\hline Ibuprofen $(40 \mathrm{mg} / \mathrm{kg} \mathrm{bw})$ & $\begin{array}{c}3.20 \pm 0.12^{\text {n.s }} \\
(1.3 \%)\end{array}$ & $\begin{array}{l}2.8 \pm 0.38^{* *} \\
(24.3 \%)\end{array}$ & $\begin{array}{l}2.6 \pm 0.14^{* * *} \\
(35.3 \%)\end{array}$ & $\begin{array}{l}2.39 \pm 0.32^{* * *} \\
(45.7 \%)\end{array}$ & $\begin{array}{c}2.20 \pm 0.02^{* * *} \\
(51.4 \%)\end{array}$ \\
\hline
\end{tabular}

In the case of analgesic models, the aqueous methanolic extract significantly reduced the number of writhings induced by acetic acid with $54.78 \pm 1.93$ and $45.32 \pm$ 1.73 at the dose of 250 and $500 \mathrm{mg} / \mathrm{kg}$ bw respectively as compared to control group (75.50 \pm 0.93$)$, whereas in the case of standard group, ibuprofen in $40 \mathrm{mg} / \mathrm{kg}$ bw dose caused highly inhibition $(69.05 \%)$ in number of writhings as shown in Table III. 
Effect of aqueous methanolic extract of Asparagus racemosus on acetic acid-induced writhing in mice

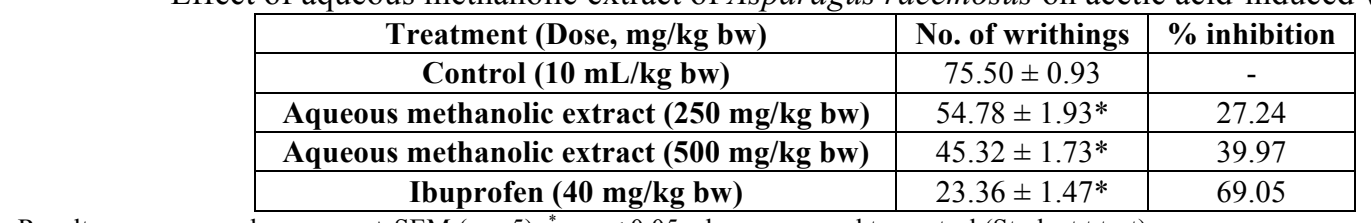

Results are expressed as means $\pm \operatorname{SEM}(n=5) ;{ }^{*}=p<0.05$ when compared to control (Student $t$ test)

The aqueous methanolic extract of Asparagus racemosus at 250 and $500 \mathrm{mg} / \mathrm{kg}$ caused significant reduction of pain response produced by formalin with maximum inhibition $76.08 \%$ and $81.62 \%$ in the first phase (first $60 \mathrm{~min}$.) and $67.94 \%$ and $75.88 \%$ in the second phase respectively. This inhibitory effect observed in the case of standard drug, ibuprofen, was $87.7 \%$ and $91.7 \%$ in first and second phase respectively as shown in Table IV.

Effect of aqueous methanolic extract of Asparagus racemosus on 2.5\% formalin induced paw licking in mice

\begin{tabular}{|c|c|c|c|c|}
\hline \multirow{2}{*}{ Treatment (Dose, $\mathbf{~ m g / k g ~ b w ) ~}$} & \multicolumn{2}{|c|}{ First phase } & \multicolumn{2}{c|}{ Second phase } \\
\cline { 2 - 5 } & Licking time (s) & \% inhibition & Licking time (s) & \% inhibition \\
\hline Control (10 $\mathbf{~ m L / k g ~ b w ) ~}$ & $168.1 \pm 0.85$ & - & $208.1 \pm 0.92$ & - \\
\hline Aqueous methanolic extract (250 $\mathbf{~ m g / k g ~ b w ) ~}$ & $40.20 \pm 5.46^{*}$ & 76.08 & $66.70 \pm 5.22^{*}$ & 67.94 \\
\hline Aqueous methanolic extract (500 $\mathbf{~ m g / k g ~ b w ) ~}$ & $30.89 \pm 7.95^{*}$ & 81.62 & $50.19 \pm 1.61^{*}$ & 75.88 \\
\hline Ibuprofen $\mathbf{4 0} \mathbf{~ m g / k g ~ b w ) ~}$ & $20.52 \pm 2.55^{*}$ & 87.79 & $17.23 \pm 0.58^{*}$ & 91.72 \\
\hline
\end{tabular}

Results are expressed as means $\pm \operatorname{SEM}(n=5) ;{ }^{*}=p<0.05$ when compared to control (Student $t$ test).

The anti-inflammatory study of the aqueous methanolic extract of Asparagus racemosus was studied in two inflammatory models, carrageenan and albumin-induced oedema model. The first method mimics acute inflammation in which carrageenan causes release of inflammatory mediators at the site of injury. This type of inflammation is indicated by swelling, pain and fever. This extract showed significant anti-inflammatory effect that might be due to the blockade of the release of mediators. Our experimental work showed resemblance with previous studies [16].

The results of our experimental work proposed that the extract showed comparable anti-inflammatory activity to standard drug ibuprofen. In first inflammatory model, carrageenan caused induction of oedema in two phases. Previous studies have shown that during the first phase (first $60 \mathrm{~min}$ ) histamine and serotonin are released while inflammatory mediators such as prostaglandins (PGs), bradykinin and lysozyme are released in the second phase (after $60 \mathrm{~min}$ ) [12]. Steroidal and non-steroidal anti-inflammatory drugs produce their response in the second phase of inflammation. Our extract produced anti-inflammatory effects by reducing paw oedema $(2.94 \pm 0.07$ and $2.74 \pm 0.04$ ) at both doses $250 \mathrm{mg} / \mathrm{kg}$ bw and 500 $\mathrm{mg} / \mathrm{kg}$ bw dose that was continued at all observable times as shown in Table I. This activity might be due to an inhibitory effect on mediators of inflammation released in both phases.

The anti-inflammatory activity of the aqueous methanolic extract of Asparagus racemosus was also studied in egg albumin-induced oedema model. The extract showed significant reduction $(2.74 \pm 0.08$ and $2.22 \pm$ 0.08 ) in paw oedema at both doses 250 and $500 \mathrm{mg} / \mathrm{kg}$ bw as shown in Table II. It is well established that histamine released from mast cells is a potent vasodilator and induces inflammation [15]. The present experimental work proposed that the extract exhibited anti-inflammatory effect that might be due to inhibition of release of inflammatory mediators such as histamine, serotonin, cytokines and prostaglandins as it was found in previous studies [17].

Acetic acid-induced writhing model has been used to evaluate the peripherally acting analgesic drugs [18]. These mediators are responsible for pain perception. In the current study, acetic acid produced 75.50 \pm 0.93 writhing in the control group as shown in Table III. The extract, in a dose dependent manner, reduced acetic acid induced writhing showing peripherally mediated analgesic activity of the extract. This peripherally mediated analgesic activity might be due to activation of peritoneal receptors present on the surface of cell lining of the peritoneal cavity [19, 20]. The extract at both doses ( 250 and $500 \mathrm{mg} / \mathrm{kg} \mathrm{bw}$ ) caused significantly reduction $(54.78 \pm 1.93$ and $45.32 \pm 1.73$ ) respectively in abdominal constrictions and jerkings. This analgesic activity might be peripherally mediated due to the inhibitory effect on the release of prostaglandins and other endogenous pain mediators in agreement with previous studies [21]. Formalin-induced paw licking model is another method used for analgesic activity evaluation. It has two phases. During the first phase, there is a direct chemical stimulation of the nociceptors, whereas the second phase depends on inflammatory mediators [22]. The extract was evaluated for both central and peripheral actions. Formalin causes increases in activation of $\mathrm{C}$ afferent fibre, indicated as paw licking in animals [23]. In the present study, paw licking time for formalin was $168.1 \pm 0.85$ seconds and $208.1 \pm 0.92$ seconds 
respectively as shown in Table IV. The aqueous extract in 250 and $500 \mathrm{mg} / \mathrm{kg}$ bw doses exhibited a significant reduction $(40.20 \pm 5.46$ and $30.89 \pm 7.95)$ in the first phase as well as in the second phase $(66.70 \pm 5.22$ and $50.19 \pm 1.61$ ) respectively (Figure 1 ). These results suggest that the analgesic effect might be due to its central as well as peripheral actions as reported by previous studies [24, 25].
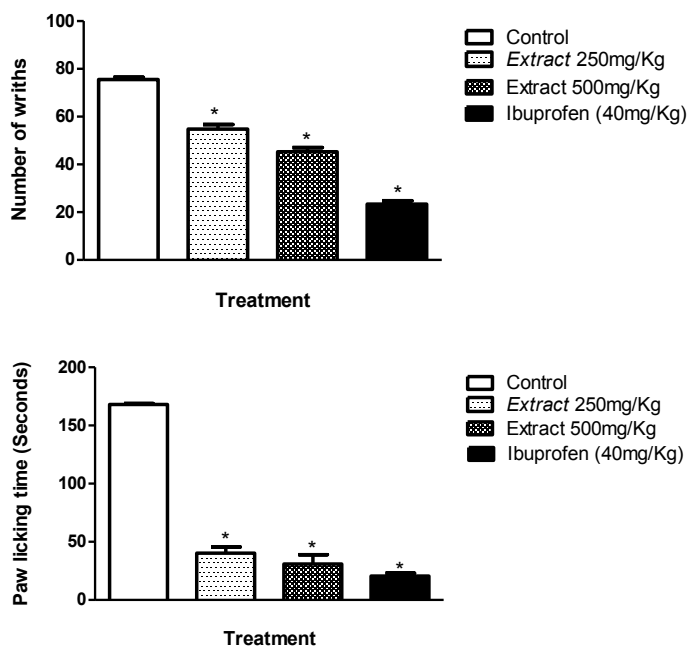

Control

Extract $250 \mathrm{mg} / \mathrm{Kg}$

Ibuprofen $(40 \mathrm{mg} / \mathrm{Kg})$

B

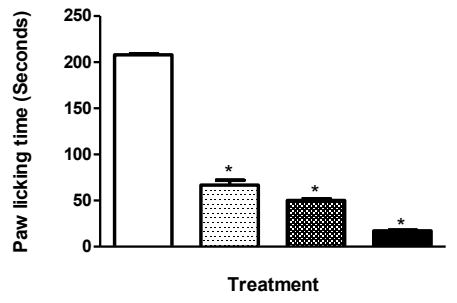

Figure 1.

Effect of Asparagus racemosus's extract on acetic acid-induced number of wriths (A) and on formalininduced paw licking time, Phase-1 (B) and Phase-11

(C) in albino mice.

$(* \mathrm{p}<0.05$ compared to control group; $\mathrm{n}=5$ )

\section{Conclusions}

Our results had shown that the aqueous methanolic extract of Asparagus racemosus exhibited analgesic and anti-inflammatory effects. It might inhibit the release of a number of mediators involved in inflammation induced by carrageenan and egg albumin in mice inflammatory models. Moreover, it significantly reduced writhing induced by acetic acid and paw lickings by formalin in mice models. Thus, these findings might be helpful for discovering new biological activities of Asparagus racemosus.

\section{References}

1. Kumar V, Abul Abbas, Nelson F, Aster J, Robbins and Cotran pathologic basis of disease, professional edition e-book. 2014.
2. Allam R, Anders HJ, The role of innate immunity in autoimmune tissue injury. Cur Opin Rheum., 2008; 20(5): 538-544.

3. Lee JH, Kim GH, Evaluation of antioxidant and inhibitory activities for different subclasses flavonoids on enzymes for rheumatoid arthritis. J Food Sci., 2010; 75(7): 212-217.

4. Gaddi A, Cicero AF, Pedro EJ, Clinical perspectives of anti-inflammatory therapy in the elderly: the lipoxigenase (LOX)/cycloxigenase (COX) inhibition concept. Arch Geront Geriat., 2004; 38(3): 201-212.

5. Phillipson JD, Phytochemistry and medicinal plants. Phytochemistry, 2001; 56(3): 237-243.

6. Ahmad I, Hussain M, Abdul Rehman, Mustafa I, Farooq M, Jabeen S, Zafer S, Threats to medicinal plant diversity in Soon valley (Salt range) of Punjab. Pakistan Int Res., 2012; 1: 158-169.

7. Anilkumar M, Ethnomedicinal plants as antiinflammatory and analgesic agents. Ethnomed., 2010; 267-293.

8. Alok S, Jain S K, Verma A, Kumar M, Mahor A, Sabharwalet M, Plant profile, phytochemistry and pharmacology of Asparagus racemosus (Shatavari): A review. Asian Pac J Trop Dis., 2013; 3(3): 242-251.

9. Kumar S, Mehla RK, Dang AK, Use of shatavari (Asparagus racemosus) as agalactopoietic and therapeutic herb - a review. Agri Rev., 2008; 29(2): 132-138.

10. Titrikou S, Kwashieeklu G, Aklessomouzou K, Messanvigbeassor. Int J Pharm Tech., 2007.

11. Ghayur MN, Gilani AH, Ginger lowers blood pressure through blockade of voltage-dependent calcium channels. J Cardio Pharm., 2005; 45(1): 74-80.

12. Akah PA, Nwambie AI, Evaluation of Nigerian traditional medicines, Plants used for rheumatic (inflammatory) disorders. J Ethnopharmacol., 1994; 42(3): 179-182.

13. Winter CA, Risley EA, Nuss GW, Carrageenininduced edema in hind paw of the rat as an assay for antiinflammatory drugs. Proc Soc Exp Biol Med., 1962; 111(3): 544-547.

14. Ocete MA, Risco S, Zarzuelo A, Jimenez J, Pharmacological activity of the essential oil of Bupleurum gibraltaricum: anti-inflammatory activity and effects on isolated rat uteri. $J$ Ethnopharmacol., 1989; 25(3): 305-313.

15. Ojewole JA, Antinociceptive, anti-inflammatory and antidiabetic effects of Bryophyllum pinnatum (Crassulaceae) leaf aqueous extract. J Ethnopharmacol., 2005; 99(1): 13-19.

16. Bhalke RD, Pal SC, Anti-inflammatory and antinociceptive activity of Pterospermum acerifolium leaves. Asian J Pharm Clin Res., 2012; 5(2): 23-26.

17. Gené R M, Segura L, Adzet T, Marin E, Iglesias J, Heterotheca inuloides: anti-inflammatory and analgesic effect. J Ethnopharmacol., 1998; 60(2): 157-162.

18. Zakaria A, Jais MR, Ishak R, Analgesic Properties of Nigella sativa and Eucheuma cottonii extracts. $J$ Nat Sc Biol Med., 2018; 9(1): 23-26.

19. Rang HP, Dale MM, Ritter JM, Flower RJ, How drugs act: cellular aspects-excitation, contraction and secretion. Rang \& Dale's Pharmacology. $6^{\text {th }}$ ed. London: Churchill Livingstone, 2007.

20. Bentley G, Newton S, Starr J, Studies on the antinociceptive action of $\alpha$ agonist drugs and their 
interactions with opioid mechanisms. Br J Pharmacol., 1983; 79(1): 125-134.

21. Panthong A, Norkaew P, Kanjanapothi D, Taesotikul T, Anantachoke N, Reutrakul V, Anti-inflammatory, analgesic and antipyretic activities of the extract of gamboge from Garcinia hanburyi Hook F. J Ethnopharmacol., 2007; 111(2): 335-340.

22. Koster R, Anderson M, De Beer E, Synthetic analgesics. Dithienbutenyl dithienbuthylamines. In Fed Proc., 1959.

23. McNamara CR, Mandel-Brehm J, Bautista DM, Siemens J, Deranian KL, Zhao M, Hayward NJ, Chong JA, Julius D, Moran MM, Fanger CM, TRPA1 mediates formalin-induced pain. $P N A S, 2007 ; 104(33)$ : 1352513530 .

24. Begum S, Saxena B, Goyal M, Ranjan R, Joshi VB, Rao CV, Krishnamurthy S, Sahai M, Study of antiinflammatory, analgesic and antipyretic activities of seeds of Hyoscyamus niger and isolation of a new coumarinolignan. Fitoterapia, 2010; 81(3): 178-184.

25. Ghannadi A, Hajhashemi V, Jafarabadi H, An investigation of the analgesic and anti-inflammatory effects of Nigella sativa seed polyphenols. J Med Food., 2005; 8(4): 488-493. 